\title{
ANIMASI KARTUN BERTEMA FALSAFAH JAWA SEBAGAI PENDIDIKAN KARAKTER BAGI ANAK USIA DINI
}

\author{
Wiekandini Dyah Pandanwangi \\ Farida Nuryantiningsih \\ Dosen Jurusan Sastra Indonesia, Fakultas Ilmu Budaya \\ Universitas Jenderal Soedirman Purwokerto \\ J1. Soeparno, Karangwangkal, Purwokerto \\ No.Hp.: 08121571986,E-mail: wiekepandanwangi@gmail.com \\ No.Hp.: 0818285384,E-mail: faridanuryanti79@gmail.com
}

\begin{abstract}
Abstrak
Latar belakang dari penelitian ini adalah adanya berbagai kasus yang bertentangan dengan nilai-nilai moral seperti korupsi yang menunjukkan rendahnya karakter dalam masyarakat. Oleh karena itu, pendidikan karakter merupakan aspek yang sangat penting dalam memperbaiki nilai moral masyarakat Indonesia. Pendekatan kebudayaan khususnya falsafah Jawa akan dijadikan landasan pendidikan karakter pada anak usia dini. Hal ini karena dalam budaya Jawa sarat akan pendidikan nilai yang merupakan substansi utama dari pendidikan karakter. Budaya Jawa memiliki pandangan hidup (yang sering disebut sebagai falsafah hidup) yang merupakan kesatuan pola pikir orang Jawa dalam menempuh kehidupan. Pendidikan karakter pada anak usia dini menjadi fondasi dasar dalam mengembangkan keterampilan sosial pada masa yang akan datang. Pendidikan karakter yang kuat dan kokoh merupakan hal yang penting dan harus ditanamkan sejak dini agar anak bangsa menjadi pribadi yang unggul seperti yang diharapkan dalam tujuan pendidikan nasional dan dapat memperkokoh bangsa dari pengaruh negatif seperti korupsi. Penelitian ini merupakan penelitian deskpritif kualitatif dengan rancangan penelitian studi kasus (case study). Lokasi penelitian adalah dua puluh Taman Kanak-Kanak terpilih di Purwokerto. Pengumpulan data menggunakan teknik in depth interview danfocus group discussion pada informan yang terpilih. Informan dipilih dengan metode purposive sample. Analisis data dilakukan dengan model analisis perbandingan dan interpretasi data. Keabsahan data akan diuji dengan triangulasi sumber dan triangulasi metode. Dalam penelitian ini, temuan yang ditargetkan adalah pembuatan model pendidikan karakter berlandaskan falsafah Jawa. Untuk membantu para guru Taman Kanak-Kanak dalam mengaplikasikan model pendidikan karakter berlandaskan falsafah Jawa, disusun modul pendidikan karakter yang berlandaskan falsafah Jawa yang berbentuk animasi kartun.
\end{abstract}

Kata kunci: pendidikan karakter, korupsi, falsafah Jawa

\begin{abstract}
Animation Cartoon Themed Philosophy of Java as Character Education for Early Childhood. The backgroud of this study is about cases which are againts moral values, such as, corruption that shows the lowness of character in the society. Because of that, character education is very important to improve Indonesian moral value. Thus, cultural approach especially Javanese philosophy is used as the foundation of character education for early childhood. This is because Javanese culture is rich in education values, that become the main substance of character education. Javanese culture has a certain point view in perceiving life (life philosophy) which represents the unity of thoughts for Javanese people to live their lives. The character education in the early childhood is the education which can be the foundation to develop social skills in the future. The strong and sturdy character education is very important to be implemented since early childhood so the future generation could become excellent children of the nation as expected in the objective of the national educationand it can make the nation stronger to avoid negative influences like corruption. This study is a descriptive qualitative research with a case study. The locations of the research are in twenty
\end{abstract}


kindergartens in Purwokerto that have been selected previously. Data collection technique is done through in depth interview and focus group discussionon from selected informants. Those selected informants are chosen using purposive sample method. Data analysis is done using comparative analysis and data interpretation. Finally, the validity is examined with triangulation resource and triangulation method. In this research, the result is a model on character education based on Javanese philosophy. To help kidergarthen teachers to apply the model, a modul in the form of animation cartoon is created.

Keywords: character education, corruption, Javanese philosophy

\section{PENDAHULUAN}

Pendidikan dalam sistem persekolahan selama ini lebih menekankan pengembangan kemampuan intelektual akademis dan kurang memberi perhatian pada aspek yang sangat fundamental, yakni pengembangan karakter (watak). Padahal, karakter merupakan aspek yang sangat penting dalam penilaian kualitas sumber daya manusia. Seseorang dengan kemampuan intelektual yang tinggi dapat saja menjadi orang yang tidak berguna atau bahkan membahayakan masyarakat jika karakternya rendah. Oleh karena itu, pendidikan karakter seharusnya ditempatkan sebagai bagian penting dalam sistem pendidikan nasional.

Berbagai kasus yang bertentangan dengan nilai-nilai moral seperti korupsi, kekerasan, kejahatan seksual, perusakan, perkelahian massa, kehidupan ekonomi yang konsumtif,kehidupanpolitikyangtidakproduktif menunjukkan rendahnya karakter yang dimiliki. Maraknya kasus yang bertentangan dengan nilai-nilai moral di Indonesia menunjukkan hal tersebut. Pemberantasan kasus-kasus tersebut tidak cukup dengan penegakan hukum semata, tetapi harus dihadapi menggunakan pendekatan kebudayaan. Salah satu upaya yang dilakukan untuk penanaman pola pikir, sikap, perilaku, dan karakter yang baik adalah melalui sekolah karena sekolah adalah proses pembudayaan. Sekolah sebagai lingkungan kedua bagi anak dapat menjadi tempat pembangunan karakter dan watak.

Pendidikan karakter pada anak usia dini menjadi pondasi dasar dalam mengembangkan keterampilan sosial pada masa yang akan datang. Oleh karena itu, peran pendidik pada masa pendidikan usia dini ini sangat penting. Pendidik perlu lebih kreatif menggunakan metode pembelajaran yang menarik dan inovatif agar dapat mengembangkan karakter positif. Pada masa ini anak-anak juga seringkali lebih percaya dan patuh kepada gurunya dibandingkan kepada orang lain termasuk orang tuanya sendiri. Pendidikan karakter yang kuat dan kokoh merupakan hal yang penting dan harus ditanamkan sejak dini agar anak bangsa menjadi pribadi yang unggul seperti yang diharapkan dalam tujuan pendidikan nasional dan dapat memperkokoh bangsa dari pengaruh negatif.

\section{METODE PENELITIAN}

Metode penelitian yang digunakan meliputi beberapa metode atau tahapan. Metode tersebut meliputi pengumpulan data, pengolahan data, perancangan karya, dan distribusi karya. Pengumpulan data diperoleh dengan cara: (1) untuk memperoleh gambaran tentang sistem pendidikan karakter yang sudah berlangsung di TK selama ini, digunakan teknik survei lapangan berupa pengamatan langsung 
di TK yang menjadi lokasi penelitian dan (2) untuk memperoleh informasi yang benar tentang sistem pembelajaran dan proses belajarmengajar di TK dilakukan dengan teknik in depth interview dan focus group discussion terhadap informan yang terpilih.

Berkaitan dengan pendidikan karakter, agar dapat dengan mudah diimplementasikan ke dalam pelajaran di sekolah, diperlukan media pembelajaran menarik. Dengan demikian, para guru dapat menyampaikan pendidikan karakter berlandaskan falsafah Jawa kepada anak didiknya yang mudah dipahami siswa. Salah satu media pembelajaran yang menarik bagi siswa sekolah dasar adalah animasi kartun. Hal ini karena dengan animasi kartun proses penerimaan pesan oleh siswa akan tersimpan lebih lama dibandingkan dengan proses pembelajaran satu arah. Selain itu, animasi kartun juga dapat memotivasi siswa agar semangat dalam memahami materi ajar akibat dari ilustrasi yang menyenangkan bagi siswa. Dengan adanya media animasi kartun sebagai sumber untuk belajar diharapkan akan mempermudah guru dan siswa dalam proses pembelajaran, sehingga dapat berjalan efektif, efisien, dan menarik.

Metode pengolahan data menggunakan metode reduksi data, pemaparan data, kategori data, dan simpulan data. Pertama, data yang tidak relevan dengan permasalahan akan dikurangi sehingga yang akan ditemukan hanyalah datadata yang mendukung permasalahan. Kedua, pemaparan data. Data hasil reduksi kemudian dipaparkan sehingga lebih memperjelas data yang sudah dikumpulkan melalui wawancara dan survei. Ketiga, kategori data. Data kemudian dikategorisasikan berdasarkan kualifikasi yang sudah ditentukan. Keempat, simpulan data dilakukan melalui pelukisan dan verifikasi. Kelima, perancangan karya dengan membuat animasi kartun berlandaskan falsafah Jawa yang relevan dengan nilai-nilai yang tercermin dalam falsafah Jawa, yang meliputi kejujuran, kepedulian, kemandirian, kedisiplinan, tanggung jawab, kerja keras, kesederhanaan, keberanian, dan keadilan.

Metode penyajian data yang telah diolah akan disajikan dalam bentuk teks naratif, yakni suatu uraian yang sistematis, logis, dan rasional sesuai dengan urutan atau posisi kepentingan data. Di samping itu, data akan disajikan pula dalam bentuk matrik, yakni suatu penyajian data dalam bentuk tabel yang diisi dengan uraian kata-kata dengan hasil wawancara dan pengamatan. Uji mutu data dilakukan dengan menggunakan triangulasi sumber dan triangulasi metode.

\section{PEMBAHASAN}

Tujuan penelitian ini adalah untuk menghasilkan media pendidikan atau pembelajaran dalam hal pendidikan karakter berlandasan falsafah Jawa dengan tujuan membentuk karakter yang berakhlak mulia pada anak-anak taman kanak-kanak dengan format modern, yaitu animasi kartun yang mempunyai tingkat ketertarikan tinggi dalam menyampaikan pesan-pesan moral. Pendidikan karakter juga bertujuan untuk meningkatkan mutu proses dan hasil pendidikan yang mengarah pada pembentukan karakter dan akhlak mulia peserta didik secara utuh, terpadu, dan seimbang, sesuai dengan standar kompetensi lulusan pada setiap satuan pendidikan. Melalui pendidikan karakter peserta didik diharapkan mampu secara mandiri meningkatkan dan menggunakan pengetahuannya, mengkaji, dan menginternalisasikan serta mempersonalisasikan nilai-nilai karakter dan 
akhlak mulia sehingga terwujud dalam perilaku sehari-hari (Mulyasa, 2011).

Sekolah dan pendidik di TK memiliki peran yang penting dan strategis untuk mengembangkan karakter positif pada anak. Pada masa ini, perkembangan anak sangat cepat sehingga perlu distimulasi agar berkembang secara optimal karena akan berpengaruh pada masa yang akan datang. Oleh karena itu, pendidik perlu menggunakan metode yang kreatif dan inovatif untuk mengoptimalkan karakter anak agar menjadi orang yang berbudi pekerti luhur. Budaya Jawa sebagai sumber pendidikan karakter tidak perlu diragukan lagi keberadaannya karena dalam budaya Jawa terdapat syarat akan pendidikan nilai yang merupakan substansi utama dari pendidikan karakter. Sudah menjadi pengetahuan umum bahwa dalam budaya Jawa terkandung tata nilai kehidupan Jawa, seperti norma, keyakinan, kebiasaan, konsepsi, dan simbol-simbol yang hidup dan berkembang dalam masyarakat Jawa. Pendidikan karakter yang digali dari substansi budaya Jawa dapat menjadi pilar pendidikan budi pekerti bangsa.

Budaya Jawa memiliki pandangan hidup (yang sering disebut sebagai falsafah hidup) yang merupakan kesatuan pola pikir orang Jawa dalam menempuh kehidupan. Falsafah hidup bagi orang Jawa merupakan ajaran kebijaksanaan, kearifan hidup, dan suatu ilmu seni kehidupan. Falsafah hidup yang mereka percayai membantu agar seseorang tidak tersesat, terseret oleh nafsu-nafsu, celaka, gagal dan putus asa. Falsafah hidup Jawa adalah saripati perjalanan hidup orang Jawa menjadi "Jawa". Jadi, identitas ke-Jawa-an tadi adalah hasil suatu proses yang panjang, melalui seleksi kualitatif misalnya seperti becik katitik ala katara yang berhubung dengan nilai-nilai kehidupan (Supadjar, 2002). Di dalam falsafah ajaran hidup Jawa, terdapat ajaran keutamaan hidup yang diistilahkan dalam bahasa Jawa sebagai piwulang (wewarah) kautaman.

Falsafah hidup bagi orang Jawa merupakan ajaran kebijaksanaan, kearifan hidup, dan suatu ilmu seni kehidupan. Falsafah hidup yang mereka percayai membantu agar seseorang tidak tersesat, terseret oleh nafsunafsu, celaka, gagal dan putus asa. Dengan demikian, seseorang yang hidup sesuai dengan norma-norma moral menjadi tanda kebijaksanaan seseorang (Suseno, 1983). Inti terpenting dari falsafah Jawa, yaitu menyangkut hubungan personal yang konkret. Falsafah Jawa tidak menyetujui apabila seseorang hanya mengusahakan kesenangan dan kepentingannya sendiri (Suseno, 1991).

Bagi keluarga Jawa, anak mempunyai kedudukan tersendiri dalam hati mereka. Ada falsafah Jawa yang mengatakan bahwa anak iku gegantelaning ati, atau anak itu tempat bergantungnya hati. Oleh karena itu, ada falsafah Jawa yang berbunyi mendhem jero mikul dhuwur, anak molah bapa kepradhah, yang berarti menimbun yang dalam dan memikul yang tinggi, anak yang berbuat bapak yang bertanggung jawab. Falsafah itu bermakna bahwa orang jawa harus mendidik anak supaya anak mempunyai kepribadian yang baik seperti, sikap saling menghormati, jujur, adil, tolong-menolong, dan tanggung jawab harus ditanamkan oleh orang tua kepada anaknya sejak dini. Hal ini dimaksudkan supaya anak dalam menghadapi kehidupanya tidak berlomba-lomba mencari keuntungan pribadi, tetapi juga membawa kebahagiaan bagi lingkungan sekitarnya seperti dalam falsafah Jawa rukun agawe santosa lan crah agawe bubrah. 
Nilai-nilai yang ditanamkan orang tua kepada anaknya tersebut adalah terkait dengan kewajiban dalam mencari penghidupan (pemenuhan kebutuhan hidup sehari-hari). Mereka akan terus mendorong anaknya dengan memberikan nilai-nilai yang arif dan memberikan sebuah perumpamaanperumpamaan sebagai tuladha (contoh). Katakata arif yang sering diucapkan oleh orang tua kepada anaknya agar mau bekerja, misalnya ana dina ana upa, artinya ada hari pasti ada rezeki; aja sangga uang "jangan berpangku tangan"; obah-mamah, lebih lengkapnya dalam sebuah nasihat sing sopo gelem obah bakal mamah, artinya siapa yang mau berusaha (bekerja) pasti akan makan (Prabowo, 2003). Nasihat tersebut memiliki arti yang sangat dalam. Obah yang berarti bergerak, menunjukkan bahwa kita harus bekerja untuk mendapatkan mamah (makan) yang berarti rezeki.

Falsafah hidup masyarakat Jawa berbeda dengan falsafah hidup masyarakat Barat (Zoetmulder dalam Endraswara, 2006). Maksudnya, falsafah Barat dikaitkan dengan mempelajari ilmu itu sendiri, sedangkan di Jawa, falsafah hihup merupakan langkah untuk mencari kesempurnaan. Falsafah Jawa menekankan laku untuk mencapai tujuan hidup yang sempurna melalui sangkan paraning dumadi dan manunggaling kawula-gusti. Kedua kutipan tersebut memberikan wawasan batin agar selalu berhati-hati dalam menjalankan hakikat hidup.

Inti terpenting dari falsafah Jawa adalah menyangkut hubungan personal yang konkret. Tuntutan social utama falsafah Jawa adalah kewajiban untuk mencegah konflik dan memelihara suasana rukun, serta untuk menghormati kedudukan semua pihak dengan menggunakan perilaku yang tepat. Falsafah
Jawa tidak menyetujui apabila seseorang hanya mengusahakan kesenangan dan kepentingannya sendiri (Suseno, 1991). Falsafah yang demikian akan membentuk orang Jawa menjadi berbudaya. Berbudaya berarti mengetahui caracara beradab dan sepenuhnya sadar akan posisi sosial (Nuryantiningsih, 2012).

Nilai-nilai falsafah Jawa tersebut merupakan implementasi wujud budi pekerti luhur. Secara alamiah, sesungguhnya manusia sudah terbekali kemampuan untuk membedakan perbuatan benar dan salah serta perbuatan baik dan buruk, maka peranan piwulang kautaman adalah upaya pembelajaran untuk mempertajam kemampuan tersebut serta mengajarkan kepada manusia untuk selalu memilih perbuatan yang benar dan baik menjauhi yang salah dan buruk. Akan tetapi, pemilihan yang benar dan baik saja tidaklah cukup untuk memandu setiap individu dalam berintegrasi dalam kehidupan bersama atau bermasyarakat. Oleh karena itu, dalam piwulang kautaman juga diajarkan pengenalan budi luhur dan budi asor di mana pilihan manusia hendaknya kepada budi luhur. Dengan demikian, setiap individu menjadi terpandu untuk selalu menjalani hidup bermasyarakat secara benar, baik, dan pener (tepat, pas).

Filosofi yang ada di balik kalimat sesanti atau unen-unen tersebut tidak cukup sekadar dipahami dengan menerjemahkan makna kata-kata dalam kalimat tersebut. Ajaran sesungguhnya dari sesanti atau i tersebut adalah pembekalan watak bagi setiap individu untuk hidup bersama atau bermasyarakat. Tujuan utamanya adalah terbangunnya kehidupan bersama yang rukun, damai, dan sejahtera. Makna dari mulat sarira dan tepa slira adalah untuk selalu mengoperasionalkan rasa pangrasa dalam bergaul dengan orang lain. Murat sarira mengajarkan untuk selalu introspeksi akan diri 
sendiri. Kesadaran untuk selalu introspeksi kepada diri sendiri akan melahirkan watak tepo sliro, berempati secara terus-menerus kepada sesama umat manusia (Nuryantiningsih, 2012).

Memahami nilai yang terkandung dalam falsafah Jawa bukanlah suatu hal yang mudah terlebih lagi untuk anak usia dini. Oleh sebab itu, nilai falsafah Jawa yang menjadi pendidikan karakter untuk anak usia dini diwujudkan dalam bentuk animasi kartun. Animasi kartun sering dikonotasikan dengan hal-hal yang lucu, dan unsure kelucuan itu antara lain dapat dilihat dari segi gambar yang sering tidak proporsional, tetapi mengena (Rahardian dalam Nurgiyantoro, 2005). Gambar-gambar dalam animasi kartun dapat dipandang sebagai alat komunikasi lewat bahasa gambar. Berdasarkan hal tersebut, animasi kartun tepat digunakan sebagai media untuk menyampaikan nilai-nilai falsafah Jawa pada anak usia dini dengan cara yang kreatif dan menyenangkan.

Berkaitan dengan pendidikan karakter, agar dapat dengan mudah diimplementasikan ke dalam pelajaran di sekolah, diperlukan media pembelajaran yang menarik. Dengan demikian, para guru dapat menyampaikan pendidikan karakter berlandaskan falsafah Jawa kepada anak didiknya yang mudah dipahami siswa. Salah satu media pembelajaran yang menarik bagi siswa sekolah dasar adalah animasi kartun. Hal ini karena dengan animasi kartun proses penerimaan pesan oleh siswa akan tersimpan lebih lama dibandingkan dengan proses pembelajaran satu arah. Selain itu, animasi kartun juga dapat memotivasi siswa agar bersemangat dalam memahami materi ajar akibat dari ilustrasi yang menyenangkan. Dengan adanya media animasi kartun sebagai sumber untuk belajar diharapkan akan mempermudah guru dan siswa dalam proses pembelajaran, sehingga dapat berjalan efektif, efisien, dan menarik.

Animasi yang digunakan untuk mengajarkan pendidikan karakter ini mempunyai tokoh utama, yaitu Bima. Tokoh Bima diambil dari nama tokoh pewayangan Pandawa. Hal ini karena selain tokoh Pandawa sudah dikenal baik oleh masyarakat sebagai tokoh protagonis, Pandawa banyak memiliki karakteryang pantas dijadikan contoh dalam sebuah pembelajaran karakter di sekolah. Sifat kasih sayang, pemaaf, sabar, bertanggung jawab, suka menolong, dan sifat baik lainnya, semua ada pada diri tokoh Pandawa. Animasi ini menggunakan metode stop motion dengan durasi yang relatif singkat, yaitu satu menit. Adapun pertimbangan dari pemilihan format tersebut adalah: (1) animasi merupakan media yang efektif dalam menyampaikan informasi bagi anak; (2) berdasarkan kuisioner yang disebar, animasi merupakan media pembelajaran yang paling digemari; (3) metode stop motion digunakan karena dampak material yang digunakan, yaitu objek papercrat sehingga menimbulkan kesan yang lebih nyata pada visualisasinya; dan (4) durasi yang singkat memungkinkan anak untuk tidak cepat bosan.

Animasi ini terdiri dari sembilan seri yang menyesuaikan dengan nilai-nilai yang terkandung dalam falsafah Jawa yang meliputi kejujuran, kepedulian, kemandirian, kedisiplinan, tanggung jawab, kerja keras, kesederhanaan, keberanian, dan keadilan. Pada tiap akhir cerita terdapat kata mutiara yang berhubungan dengan pesan yang disampaikan. Hal tersebut diterapkan agar anak dapat lebih mudah mencerna pesan yang terkandung pada tiap episodenya. Berikut ini disajikan bentuk animasi kartun berdasar falsafah Jawa sebagai penidikan karakter bagi anak usia dini. 


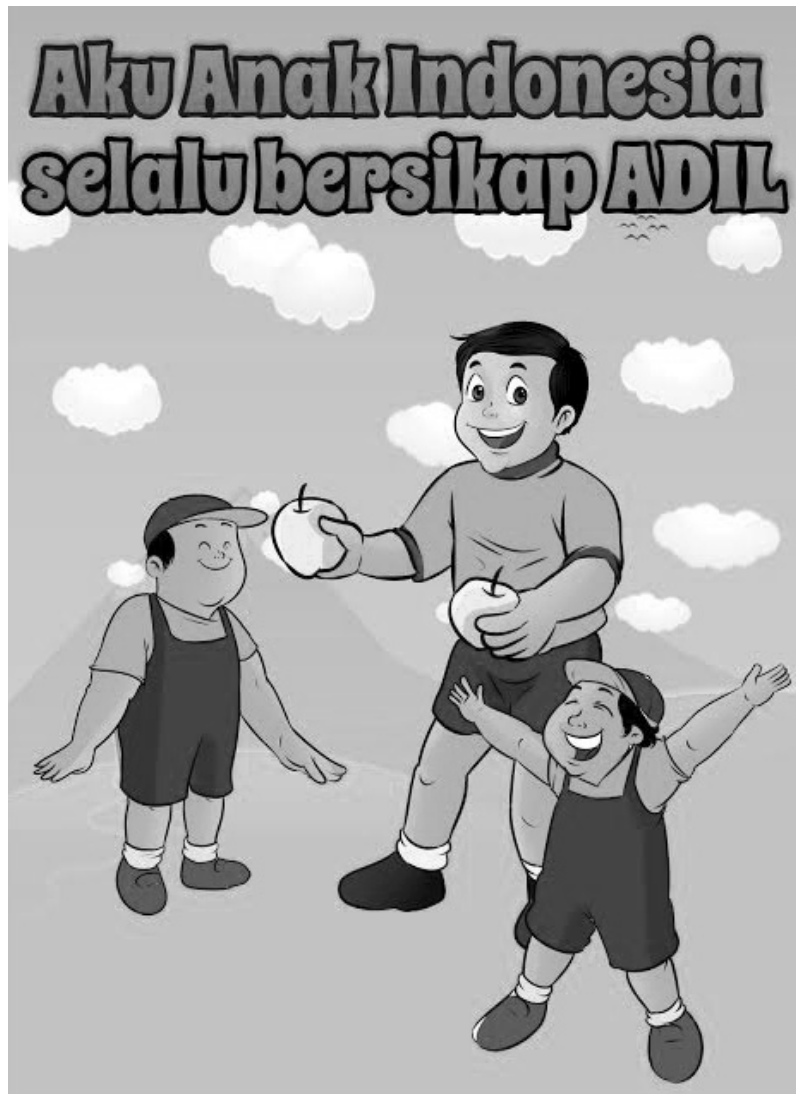

Contoh Animasi Kartun Anak Bertema Keadilan

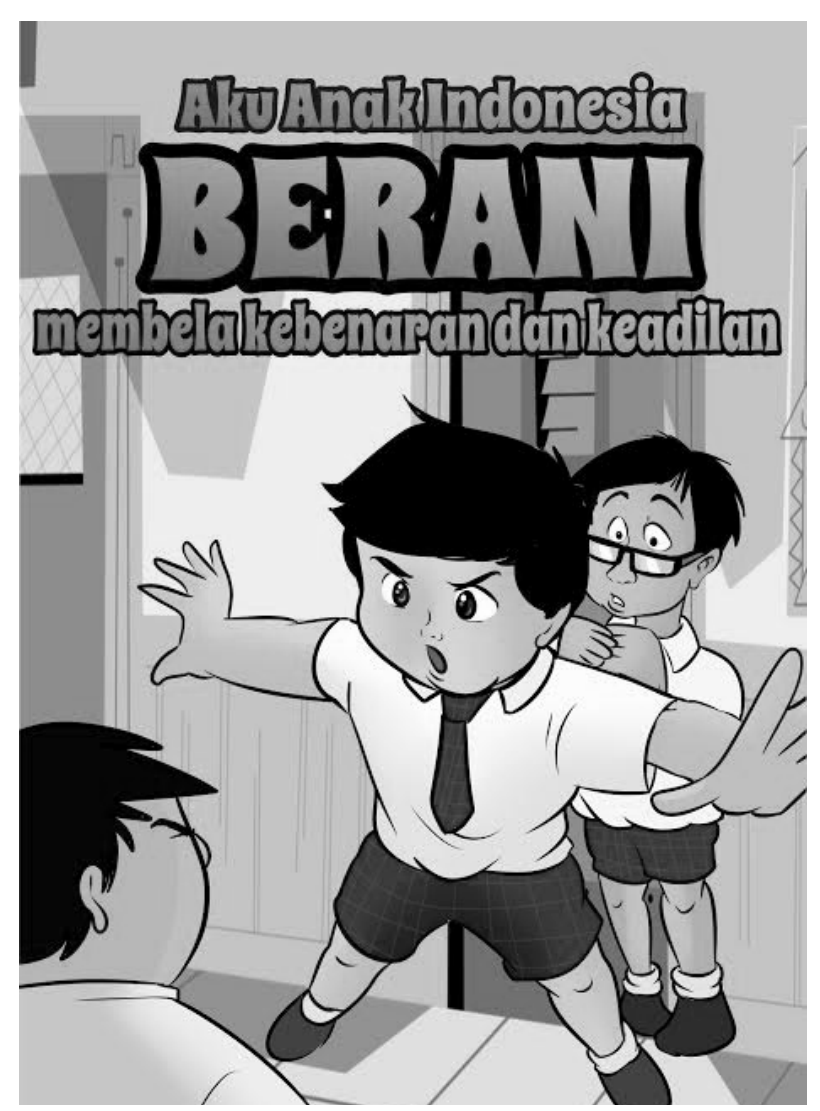

Contoh Animasi Kartun Anak Bertema Keberanian

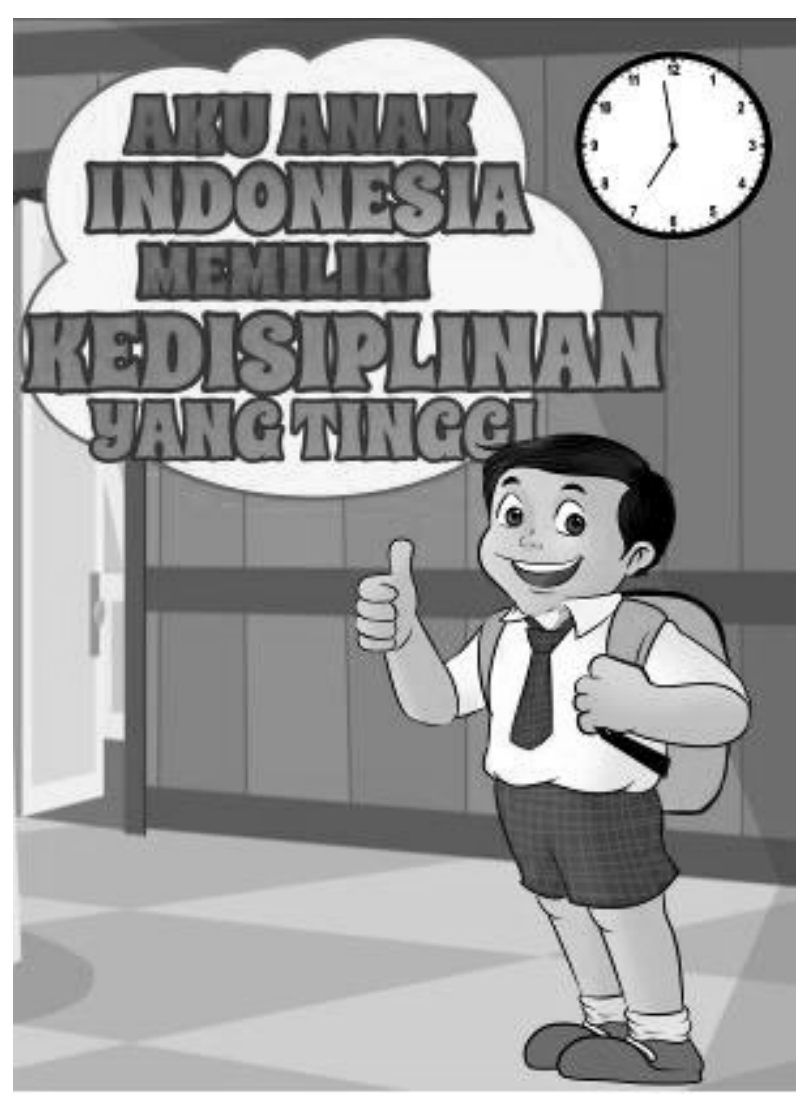

Contoh Animasi Kartun Anak Bertema Kedisiplinan

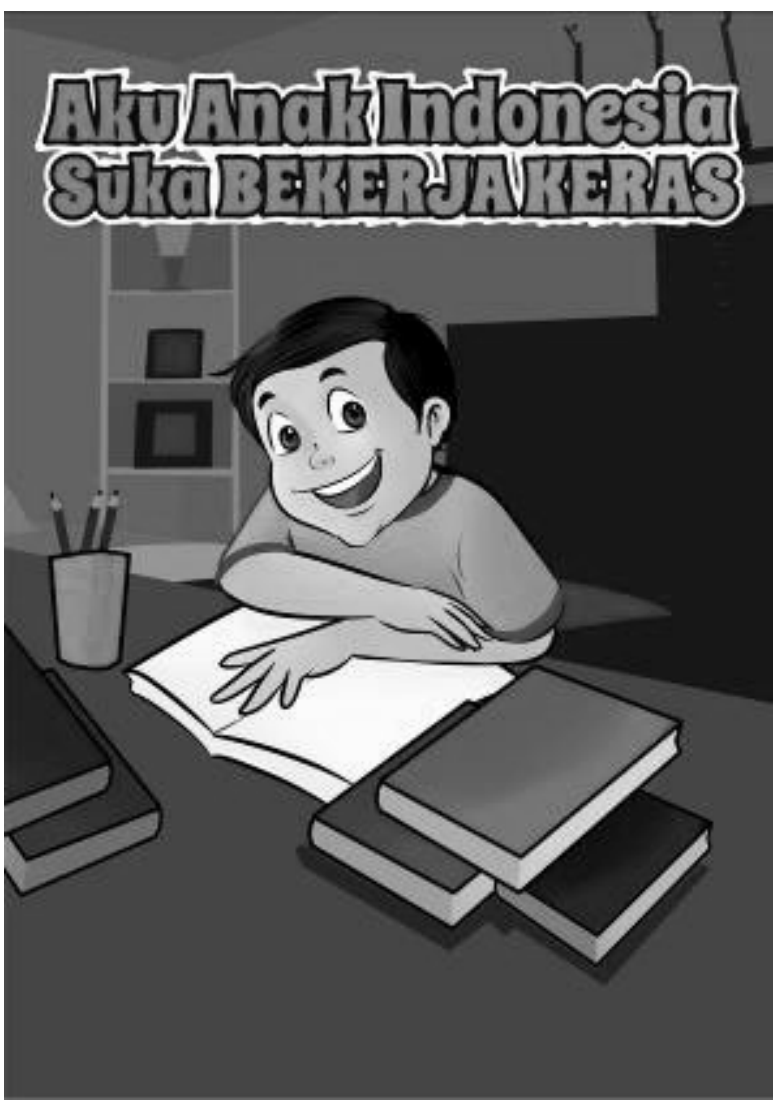

Contoh Animasi Kartun Anak Bertema Kerja Keras 


\section{SIMPULAN}

Banyak hal yang harus diperhatikan dalam pembuatan animasi untuk anak agar pesan yang terkandung dapat tersampaikan sehingga dapat memengaruhi karakter anak. Hal-hal yang perlu diperhatikan tersebut antara lain: (1) cerita tidak terlalu rumit dan tidak membosankan; (2) cerita harus disesuaikan dengan tujuan yang akan dicapai; dan (3) visualisasi harus disesuaikan dengan selera anak.

Gaya visual yang sesuai untuk anak adalah gaya visual yang mempunyai sifat cute design. Objek-objek visual menggunakan elemen-elemen keseharian yang dekat dengan keseharian anak. Warna yang digunakan tak perlu dibatasi namun harus tetap harmoni dan tidak ramai.

Selain itu, berdasarkan pembahasan dapat dikatakan bahwa nilai-nilai dalam falsafah Jawa dapat diterapkan sebagai pendidikan karakter. Hal tersebut karena nilainilai dalam falsafah Jawa mengajak sesorang untuk selalu melakukan kebaikan, berlaku jujur, senang bekerja keras untuk mendapatkan sesuatu, senantiasa rendah hati, tidak silau terhadap kemewahan duniawi, dan peduli kepada sesama.

\section{KEPUSTAKAAN}

E. Mulyasa. (2011). Manajemen Pendidikan Karakter. Jakarta: PT Bumi Aksara.

Endraswara, S. (2006). Falsafah Hidup Jawa. Yogyakarta: Cakrawala.

Julianto, D. dan M. I. R. (2014). Perancangan Serial Animasi 3D "Steven's habits" sebagai Media Pendidikan Karakter yang Efektif untuk Anak melalui Prinsip 7 Habits.

Nurgiyantoro, B. (2005). Sastra Anak: Pengantar Pemahaman Dunia Anak. Yogyakarta: Gadjah MadaUniversity Press.
Nuryantiningsih, F. \& W. (2012). Peran Falsafah Jawa sebagai Kearifan Lokal dalam Membentuk Karakter Masyarakat Yogyakarta. Universitas Jenderal Soedirman.

Prabowo, D. P. (2003). Pengaruh Islam dalam Karangan R.Ng. Ronggowarsito. Yogyakarta: Narasi.

Supadjar, D. (2002). Nawang Sari (ButirButir Renungan Agama- SpiritualitasBudaya). Yogyakarta: Adipura.

Suseno, F. \& R. (1983). Etika Jawa dalam Tantangan Sebuah Bunga Rampai. Yogyakarta: Penerbit Kanisius.

Suseno, F. M. (1991). Etika Jawa Sebuah Analisa Falsafi Kebijaksanaan Hidup Jawa. Jakarta: PT. Gramedia. 